\title{
KAJIAN HEGEMONI DALAM BERTINDAK TUTUR GURU PADA PEMBELAJARAN BAHASA INDONESIA DI SMP NEGERI 1 PANGKEP KABUPATEN PANGKEP
}

\author{
Supriani Idris \\ SMP Negeri 1 Pangkep, Kabupaten Pangkep \\ supriadi_idris@yahoo.co.id.
}

\begin{abstract}
Hegemony is an embodiment of the power of the teacher as a managerial class emphasizes the bourgeois form of expression and like always indoctrinate students in several ways the application, run mechanism to maintain, and develop themselves through obedience to the students so that an attempt was made to influence and shape the minds of students. In this study the function of hegemony representasidan described in learning Indonesian teacher at SMP Negeri 1 Bungoro Pangkep. This study used a qualitative research approach. The research data recorde of the speech act hegemony in learning Indonesian teacher at SMP Negeri 1 Bungoro Pangkep and field notes. The Sources of data were Indonesian teacher at SMP Negeri 1 Bungoro Pangkep. Thus, the data source of this research was all the Indonesian teacher who was still active in teaching. Technic of data collection were observation and recording. Analisis the data flow analysis performed by embracing the concept of data flow model of Miles and Huberman. The results showed that the hegemony of the acting teacher speaking on learning Indonesian in SMP Negeri 1 Bungoro Pangkep represented in the followdirective, assertive, and expressive. Representation hegemony in the follow-directive, the teacher as authority in the classroom using five types of directives, ie commands, requests, prohibitions, persilaan, questions, and rejection. The use of the speech act has a high level of restriction that tend to represent the dominating power. Hegemony in the follow-assertive representation, the teacher as authority in the classroom using three types of follow-assertive, that is asserted, indicating, mempertahankan. Using assertive showed the nature of the dominating power of the students. Follow-expressive anger represented in the form of teachers who also have high levels of restriction that is dominating. Hegemonic function of speech acts on learning Indonesian teacher at SMP Negeri 1 Bungoro Pangkep represented in the commission of preventive and corrective. Associated with preventive measures, hegemony functioned to prevent violations of the rules in learning. As corrective action, hegemony functioned to improve student actions, behavior of students in learning, and how students working in the task.
\end{abstract}

Key Words: Hegemony, speech acts, and learning

\begin{abstract}
Abstrak
Hegemoni adalah suatu perwujudan kekuasaan guru sebagai manajerial kelas yang menekankan pada bentuk ekspresi dan layaknya borjuis yang selalu mendoktrin siswa melalui beberapa cara penerapan, mekanisme yang dijalankan untuk mempertahankan, dan mengembangkan diri melalui kepatuhan para siswa sehingga upaya itu berhasil memengaruhi dan membentuk alam pikiran siswa. Dalam penelitian ini dideskripsikan representasidan fungsi hegemoni dalam bertindak tutur guru pada pembelajaran bahasa Indonesia di SMP Negeri 1 Bungoro Kabupaten Pangkep. Penelitian ini menggunakan pendekatan penelitian kualitatif. Data penelitian ini berupa rekaman tentang hegemoni dalam bertindak tutur guru pada pembelajaran bahasa Indonesia di SMP Negeri 1
\end{abstract}


Bungoro Kabupaten Pangkep dan catatan lapangan. Sumber data, yaitu guru bahasa Indonesia di SMP Negeri 1 Bungoro Kabupaten Pangkep. Jadi, sumber data penelitian ini adalah semua guru bahasa Indonesia yang masih aktif dalam mengajar. Teknik pengupulan data yaitu observasi dan perekaman.Analisis data dilakukan dengan menganut alur analisis data model alir konsep Miles dan Huberman. Hasil penelitian menunjukkan bahwa hegemoni dalam bertindak tutur guru pada pembelajaran bahasa Indonesia di SMP Negeri 1 Bungoro Kabupaten Pangkep direpresentasikan dalam tindak direktif, asertif, dan ekspresif. Representasi hegemoni dalam tindak direktif, guru sebagai pemegang kekuasaan di kelas menggunakan lima jenis direktif, yaitu perintah, permintaan, larangan, persilaan, pertanyaan, dan penolakan. Penggunaan tindak tutur tersebut mempunyai kadar retriksi tinggi sehingga cenderung merepresentasikan kekuasaan yang dominatif. Representasi hegemoni dalam tindak asertif, guru sebagai pemegang kekuasaan di kelas menggunakan tiga jenis tindak asertif, yaitu menegaskan, menunjukkan, mempertahankan.Penggunaan tindak asertif ini menunjukkan sifat kekuasaan yang dominatif terhadap siswa. Tindak ekspresif direpresentasikan dalam bentuk kemarahan guru yang juga memiliki kadar retriksi yang tinggi sehingga bersifat dominatif. Fungsi hegemoni tindak tutur guru pada pembelajaran bahasa Indonesia di SMP Negeri 1 Bungoro Kabupaten Pangkep direpresentasikan dalam tindak preventif dan korektif. Terkait dengan tindakan preventif, hegemoni difungsikan untuk mencegah pelanggaran aturan dalam pembelajaran. Adapun tindakan korektif, hegemoni difungsikan untuk memperbaiki tindakan siswa, perilaku siswa dalam belajar, dan cara kerja siswa di dalam mengerjakan tugas.

\section{Key Words:Hegemoni, tindak tutur, dan pembelajaran}

\section{PENDAHULUAN}

Kajian terhadap bahasa lisan dalam interaksi kelas merupakan kajian pragmatis.Dalam penelitian ini dilakukan analisis terhadap bahasa lisan dalam interaksi kelas untuk melihat dimensi sosial yang terdapat dalam praktik pembelajaran di dalam kelas tersebut.

Hal tersebut dilakukan melihat kenyataan di kelas yang menunjukkan adanya sejumlah praktik sosial yang menggambarkan hegemoni guru terhadap siswa.Terdapat pula praktik pemunculan otoritas guru baik sebagai pengatur disiplin maupun sebagai pemberi materi.Ada pula dominasi guru di dalam kelas dan juga guru menjadi orang yang serba tahu. Terdapat pula ketidakkonsistenan guru dalam praktik perilakunya di depan kelas. Di satu sisi, guru menginginkan jawaban yang mendalam ketika siswa menjawab pertanyaan di sisi lain guru menunjukkan ketidaksabarannya menunggu siswa menjawab. Sementara itu, terdapat perubahan perilaku pada pertengahan proses pembelajaran. Guru mengubah fungsinya dalam koridor paradigma konvensional ke paradigma nonkonvensional.

Kegagalan ruang kelas adalah manakala guru kehilangan apresiasi terhadap kerja-kerja kreatif siswa.Lebih problemaatik, guru kerap apresiatif hanya terhadap siswa yang pintar dan tidak banyak berbuat ulah macammacam.Sementara bagi yang hiperaktif dan cenderung onar, dianggap sebagai pengacau yang harus segera didiamkan agar tak mengganggu stabilitas.Di sini kelas tak ubahnya Negara yang selalu dan selamanya mewaspadai gerakan-gerakan protes.Pengganggu stabilitas macam ini 
dianggap sebagai subversif dan segera harus diganyang agar tak menjalar.

Siswa mencari suasana yang jauh dari tekanan, baik fisik maupun mental.Belajar menjadi sesuatu yang tidak menarik, intimidatif dan penuh aroma otoritarian jika orang dewasa (dalam hal ini guru) mengedepankan pendekatan refresif.Sejalan dengan ungkapan bahwa "setiap bocah adalah seniman.masalahnya tinggal cara mempertahankan agar ia tetap artis ketika sudah dewasa". Jika demikian, Kalau pendekatan guru dalam memelihara suasana pembelajaran di kelas, tentu saja anak-anak bukan tipe pembangkang seperti orang dewasa, yang mampu dilakukan hanya semata-mata dengan diam tak bereaksi selama pembelajaran. Siswa akan bereaksi dengan membuat gaduh semakin gaduh. Ketika suasana kelas berhasil dikuasai guru dengan menomorsatukan ketenangan dalam bentuk paling buruk, yaitu mendiamkan siswa dengan 'menjinakkan'nya, beberapa guru merasa pencapaiannya sudah sangat bagus dan mumpuni. Inilah alienasi siswa dari 'habitat' ilmu pengetahuannya sendiri oleh guru atas nama kenyamanan guru semata yang tidak ingin bersusah payah.

Fenomena lain yang tergambar adalah ruang kelas adalah ruang menjauhkan siswa dari masa kanakkanaknya, beragam cara yang dilakukan guru agar siswa dapat duduk tenang mencatat apa yang diktekan di depan. Siswa duduk layaknya tentara yang kaku mendengar penjelasan tentang tema pembelajaran, atau mencatatnya kembali. Situasi pembelajaran seperti ini bukan hal buruk baru dalam dunia pendidikan, tetapi 'virus' lama yang menjangkiti guru sepanjang kesadarannya belum berubah tentang apa dan bagaimana 'dominasi' yang berujung pada 'hegemoni' itu.
Ruang kelas tak ubahnya miniatur sosial tempat dominasi/hegemoni antara guru siswa berebut tempat.Secara sopan dan terselubung saling menguasai.Sayangnya, meskipun jumlah siswa lebih banyak dari guru, guru berhasil mendominasi. Dalam bahasa Antonio Gramsci "a social condition in which all aspects of social reality are dominated by or supportive of a single class". Dominasi guru dalam ruang kelas tercermin dari penafian dialog setara antara guru-murid ketika menentukan metode pembelajaran dan target yang hendak dicapai dari PBM. Guru lebih menyerupai sekelompok kelas tunggal dalam masyarakat, dengan posisi tak tergoyahkan bebas menentukan sendiri metode belajar, arah yang ingin dicapai dari PBM. Namun, guru bukan satu-satunya kelas dominan, di atasnya berdiri kelas yang jauh lebih kuat dan mapan.

Berbagai dominasi sebagai bentuk hegemoni guru tersebut terealisasi dari wujud tutur guru yang semena-mena tanpa memandang siswa sebagai pelaku sosial yang perlu dihargai.Guru di kelas adalah sosok orator yang tuturan deklaratif dan imperatifnya tak terbantahkan oleh siswa.Ketika guru menyatakan kumpul tugasnya, maka siswa dengan spontan mengumpulnya.Jika guru menyatakan baca bukunya, lalu kerjakan soal-soalnya, maka siswa membaca dan bekerja.Ketika guru menjelaskan dan menginformasikan materi, tak satu pun siswa protektif.Hal inilah yang merupakan wujud dominasi guru dalam bertutur di kelas.

Pada hakikatnya perilaku guru di dalam proses pembelajaran di dalam kelas merupakan refleksi dari ideologi yang dianutnya. Dengan melihat perilaku guru dalam bertindak di dalam kelas akan tergambar bagaimana guru memandang posisi siswa. Apakah guru memandang 
siswa berdasarkan konsep atasan-bawahan ataukah berdasarkan konsep bahwa guru sebagai motivator dan fasilitator serta siswa sebagai patner (mitra).Hal itu merupakan realisasi dari sistem pikiran dan kepercayaan yang ada pada diri guru itu sendiri.

\section{KAJIAN TEORI}

\section{A. Hegemoni}

Istilah hegemoni berasal dari istilah yunani, hegeisthai. Hegemoni bisa didefinisikan sebagai: dominasi oleh satu kelompok terhadap kelompok lainnya, dengan atau tanpa ancaman kekerasan, sehingga ide-ide yang didiktekan oleh kelompok dominan terhadap kelompok yang didominasi diterima sebagai sesuatu yang wajar (common sense). Konsep hegemoni banyak digunakan oleh sosiolog untuk menjelaskan fenomena terjadinya usaha untuk mempertahankan kekuasaan oleh pihak penguasa.Penguasa disini memiliki arti luas, tidak hanya terbatas pada penguasa negara (pemerintah).

Konsep hegemoni dipopulerkan ahli filsafat politik terkemuka Italia, Antonio Gramsci yang berpendapat bahwa kekuatan dan dominasi kapitalis tidak hanya melalui dimensi material dari sarana ekonomi dan relasi produksi, tetapi juga kekuatan (force) dan hegemoni. Jika yang pertama menggunakan daya paksa untuk membuat orang banyak mengikuti dan mematuhi syarat-syarat suatu cara produksi atau nilai-nilai tertentu, maka yang terakhir meliputi perluasan dan pelestarian "kepatuhan aktif" yang secara sukarela dari kelompok-kelompok yang didominasi oleh kelas penguasa lewat penggunaan kepemimpinan intelektual, moral, dan politik. Hegemoni menekankan pada bentuk ekspresi, cara penerapan, mekanisme yang dijalankan untuk mempertahankan, dan mengembangkan diri melalui kepatuhan para korbannya sehingga upaya itu berhasil memengaruhi dan membentuk alam pikiran (Eriyanto, 2003: 105).

Dalam hegemoni, kelompok yang mendominasi berhasil mempengaruhi kelompok yang didominasi untuk menerima nilai-nilai moral, politik, dan budaya dari kelompok dominan (the ruling party, kelompok yang berkuasa).Hegemoni diterima sebagai sesuatu yang wajar, sehingga ideologi kelompok dominan dapat menyebar dan dipraktikkan. Nilai-nilai dan ideologi hegemoni ini diperjuangkan dan dipertahankan oleh pihak dominan sedemikian sehingga pihak yang didominasi tetap diam dan taat terhadap kepemimpinan kelompok penguasa.Hegemoni bisa dilihat sebagai strategi untuk mempertahankan kekuasaan.

\section{B. Hegemoni Bertindak Tutur dalam Pembelajaran \\ Pada hakikatnya, bahasa} merupakan produk budaya.Sebagai produk budaya, bahasa mempunyai beragan fungsi.Thompson (1990: 84) menyatakan bahwa bahasa bukan sekadar alat komunikasi atau pengetahuan, melainkan sebagai alat kekuasaan (hegemoni). Hal ini didasarkan pada kenyataan bahwa dalam proses komunikasi, penutur berusaha untuk tidak hanya dipahami, tetapi untuk dipercaya, dipatuhi, dihormati, dan dibedakan.

Dalam realisasinya, fungsi bahasa sebagai alat kekuasaan (hegemoni) terjadi dalam proses komunikasi verbal, baik yang bersifat transaksional maupun interaksional. Dalam konteks ini, bahasa menyediakan unsur-unsur yang memungkinkan para penutur mengembangkan tindak tutur dan 
strategi tutur tertentu untuk memengaruhi atau bahkan mendominasi perasaan, pikiran, dan perilaku petutur.Gejala ini dapat terjadi dalam berbagai peristiwa tutur, baik dalam institusi politik, ekonomi, sosial, pendidikan, dan budaya.

Kenyataan tersebut mendapat pembenaran dari Fairclough (1998: 34) bahwa kekuasaan dapat terjadi dalam hubungan kelas sosial, hubungan antarkelompok dalam suatu institusi, hubungan antarkelompok etnis, hubungan antara pria dan wanita, hubungan antara orang tua dan anak/guru dan siswa. Bahkan, van Dijk (1998: 5) menyatakan bahwa kekuasaan (hegemoni) dapat terjadi dalam semua aspek kehidupan.Misalnya, militer menggunakan paksaan untuk membangun kekuasaannya, orang tua menggunakan bentuk-bentuk persuasif, profesor dan jurnalis menggunakan pengetahuan, informasi, dan otoritasnya, hubungan kelas, gender, dan ras.

\section{Tindak Tutur}

Tindak tutur merupakan fenomena pragmatik penyelidikan linguistik klinis yang sangat menonjol. Penggunaan dan pemahaman pragmatik telah diselidiki dalam kondisi-kondisi klinis dengan cara sama beragamnya seperti autisme, ketidakmampuan belajar, penyakit Alzheimer, cedera kepala tertutup dan kerusakan belahan otak kiri. Pada kondisikondisi dimana kapasitas seseorang untuk memulai komunikasi belum berkembang secara normal (autism) atau terusmenerus mengalami kerusakan (penyakit Alzheimer), pemroduksian tindak tutur merupakan indikator penting bagi fungsi pragmatik. Pada kondisi-kondisi lainnya, subjek mengubah sifat langsung berbagai tindak tersebut sesuai dengan pertimbangan-pertimbangan kesantunan. Masih kondisi-kondisi yang lain, subjek mungkin tidak dapat mengetahui maksud penutur dalam memproduksi suatu ujaran. Hal ini menimbulkan berbagai implikasi dalam konteks yang ada untuk memahami tindak tutur-tindak tutur tak langsung (penutur yang berkata It's warm in here dengan maksud meminta pendengar untuk mengecilkan atau mematikan alat pemanas ruangan). Singkat kata tindak tutur merupakan kategori yang kaya akan fenomena-fenomena pragmatik untuk dikaji oleh para ahli linguistik klinis, (Louise, 2007: 362-363).

\section{METODE PENELITIAN}

\begin{tabular}{llr}
\multicolumn{2}{c}{ Penelitian ini } & menggunakan \\
pendekatan penelitian & kualitatif.
\end{tabular} Pendekatan kualitatif memiliki karakteristik (1) berlatar alamiah, (2) bersifat deskriptif, (3) lebih mementingkan proses daripada hasil, (4) analisis data dilakukan secara induktif, dan (5) makna sebagai suatu hal yang esensial (Biklen dan Bogdan, 1982:27-30; Miles dan Huberman, 1992:1; Ibrahim, 1994:276; Lincoln dan Guba (dalam Moleong, 2001:4-8).

Penelitian ini berlatar alamiah peneliti sekaligus berfungsi sebagai instrumen utama. Kegiatan pelaksanaan pengumpulan data langsung pada konteks terjadinya tuturan yang bermuatan implikatur tindak direktif dan tidak dikondisikan (dimo-difikasi). Alat bantu yang digunakan dalam pengambilan data adalah pedoman observasi yang berfungsi mencatat data yang bermuatan hegemoni dalam bertindak tutur guru pada pembelajaran bahasa Indonesia di SMP Negeri 1 Bungoro Kabupaten Pangkep dan tape recorder yang berfungsi untuk merekam data hegemoni dalam bertindak 
tutur guru pada pembelajaran bahasa Indonesia di SMP Negeri 1 Bungoro Kabupaten Pangkep.

Data penelitian ini berupa rekaman tentang hegemoni dalam bertindak tutur guru pada pembelajaran bahasa Indonesia di SMP Negeri 1 Bungoro Kabupaten Pangkep dan catatan lapangan. Data catatan lapangan diperoleh melalui observasi terhadap percakapan dan tindak tutur guru. Sementara itu, data rekaman diperoleh dari perekaman tuturan guru bahasa Indonesia yang mengandung hegemoni.

Kedua jenis data tersebut diperoleh dari sumber data, yaitu guru bahasa Indonesia di SMP Negeri 1 Bungoro Kabupaten Pangkep. Jadi, sumber data penelitian ini adalah semua guru bahasa Indonesia yang masih aktif dalam mengajar.

Penelitian ini dilakukan dengan harapan dapat memberikan gambaran yang jelas dan konkret tentang hegemoni dalam bertindak tutur guru pada pembelajaran bahasa Indonesia di SMP Negeri 1 Bungoro Kabupaten Pangkep. Agar harapan tersebut dapat tercapai dalam penelitian ini digunakan teknik pengupulan data (1) observasi dan (2) perekaman.

Analisis data dilakukan dengan menganut alur analisis data model alir. Miles dan Huberman (1992:15-20) mengemukakan bahwa teknik analisis data model alir memiliki dua ciri yang menonjol, yakni (1) model analisis data dan (2) analisis data selama dan setelah pengumpulan data. Model analisis data yang digunakan dalam penelitian ini mencakup empat langkah kegiatan, yakni (1) pengumpulan data, (2) reduksi data, (3) penyajian data, dan (4) penyimpulan/verifikasi. Analisis data dapat dilakukan selama pengumpulan data dan setelah pengumpulan data berakhir.
Analisis data pada saat pengumpulan data diperlukan untuk menyeleksi data-data yang ber-hubungan dengan rumusan permasalahan. Sementara itu, analisis data setelah pengumpulan data mengacu pada kerangka kerja kualitatif yaitu pengumpulan data catatan lapangan dan rekaman.

\section{HASIL PENELITIAN}

1. RepresentasiHegemoni dalam Bertindak Tutur Guru pada Pembelajaran Bahasa Indonesia di SMP Negeri 1 Bungoro Kabupaten Pangkep

\section{a. Representasi Hegemoni dalam Tindak Direktif \\ 1) Representasi Hegemoni dalam Perintah}

Salah satu tindak direktif adalah memerintah. Data berikut ini berwujud imperatif perintah anjuran yang ditemukan dalam interaksi belajar mengajar di SMP Negeri 1 Bungoro Kabupaten Pangkep.

Konteks Tuturan:

$\begin{array}{ll}\text { Guru: } & \begin{array}{l}\text { Bagaimana } \\ \text { ujiannya? (1) }\end{array} \\ \text { Siswa: } & \begin{array}{l}\text { Kurang memuaskan } \\ \text { Bu. (2) }\end{array} \\ \text { Guru: } & \begin{array}{l}\text { Kalau kamu semua } \\ \text { mau mendapat nilai }\end{array} \\ & \text { bagus, tingkatkan cara } \\ & \text { belajarnya, ya! pasti } \\ & \text { nilai semakin } \\ & \text { meningkat dan lebih } \\ & \text { bagus lagi. (3) }\end{array}$
dikemukakan bahwa tuturan direktif dalam bentuk perintah guru terhadap siswa. Tuturan direktif guru yang berwujud imperatif perintah tampak pada data (3), 
yakni kalau kaти sетиа mau mendapat nilai bagus, tingkatkan cara belajarnya, ya! pasti nilai semakin meningkat dan lebih bagus lagi. Tuturan direktif perintah tersebut muncul sebagai respons guru terhadap siswa yang menanyakan nilai ulangan hariannya. Dalam merespons pertanyaan siswa, guru juga meresponsnya kembali dengan menggunakan tindak direktif memerintah. Implikasinya adalah guru memerintah siswa untuk giat belajar supaya dapat memperoleh nilai yang maksimal.

Konteks tuturan:

$\begin{array}{ll}\text { Siswa 1: } & \text { Terima kasih saran } \\ & \text { dan pertanyaannya } \\ & (4) \\ \text { Guru: } & \text { Iya, memang } \\ & \text { seharusnya } \\ & \text { dijelaskan satu- } \\ & \text { satu bagian itu } \\ & \text { supaya semuanya } \\ & \text { tahu namanya per } \\ & \text { bagian itu. Ingat } \\ & \text { saran dan } \\ & \text { pertanyaan dijawab } \\ & \text { semua ya, supaya } \\ & \text { saya tidak perlu } \\ & \text { lagi menjelaskan } \\ & \text { ulang (5). }\end{array}$

Tuturan (5) tersebut merupakan direktif perintah anjuran. Hal ini ditandai oleh penggunaan kata ingat yang mengindikasikan bahwa guru menganjurkan dan memberi peringatan kepada siswa agar menjelaskan materi supaya semua jelas. Selain itu, perintah guru mengindikasikan tujuan guru yang ingin meringankan bebannya sebagai pemberi pengetahuan dan menjelaskan materi penguatan.

Dominasi guru pada tindak direktif ingat saran dan pertanyaan dijawab sетиа ya, supaya saya tidak perlu lagi menjelaskan ulang (5) ditandai oleh peringatan guru dengan menggunakan kata ingat. Penggunaan kata ingat telah mendominasi ruang gerak dan kebebasan sehingga siswa kaku, tegang, dan tertekan karena merasa takut jika tidak menjawab semua pertanyaan dengan baik.

\section{2) Representasi Hegemoni dalam Permintaan}

Tuturan hegemoni guru yang berwujud permintaan dalam interaksi belajar mengajar tampak dialog guru-siswa seperti berikut ini.

Guru: Perhatikan semua!

(6)

Siswa 1: Iya, Pak. (7)

Siswa 2: Bagaimana mau memperhatikan, yang lain banyak ribut dan bercerita?

(8)

Guru: Kalian dengar tidak, bisakah kalian perhatikan?

Isi pembicaraan antara guru dengan siswa sesuai dengan dialog tersebut adalah permintaan guru kepada siswa. Dalam hal ini, guru meminta kepada siswa agar memperhatikan materi dan penjelasan yang disampaikan oleh guru. Dalam menyampaikan perintah ini, tentu guru menggunakan kalimat perintah yang tidak langsung yang implikasinya menyuruh siswa untuk memperhatikan penjelasan guru. Tuturan permintaan guru tampak pada data ( 6), yakni perhatikan semua. Tindak direktif ini bermakna permintaan guru terhadap siswa. Namun, dalam konteks tersebut guru memanfaatkan otoritas dan kekuasaanya di kelas. Perintah perhatikan sетиа memiliki pengaruh yang lebih kuat, 
keras, dan bertekanan jika dibandingkan dengan perintah mohon diperhatikan.

Tindak direktif guru dengan dominasi dan kekuasaannya dalam pembelajaran tampak pula pada data berikut ini.

Guru: Assalamu alaikum dan selamat pagi semuanya! (10)

Siswa: Alaikum mussalam. Pagi Bapak (11)

Guru: Bagaimana hari ini, hadir semua? (12)

Siswa: Iya Pak.(13)

Guru: Ok, bagaimana tugasnya pada pertemuan yang lalu? Semua harus melaporkan jika tidak mau mendapat hukuman (14)

Siswa: Tugas yang menganalisis unsur sastra kan Pak (15)

Pada konteks tuturan tindak direktif guru (14), tampak implikasi permintaan guru terhadap siswa. Dalam merealisasikan permintaan tersebut, guru menunjukkan dominasinya kepada siswa dengan intimidasi dan ancaman bagi siswa yang tidak menyelesaikan pekerjaannya. Pada konteks ini pula menunjukkan bahwa siswa seperti dalam tekanan guru yang menimbulkan ketidakberdayaan bagi siswa. Tuturan permintaan guru yang demikian tentunya kurang humanis sehingga terdapat jarak status antara guru dengan siswa.

\section{3)Representasi Hegemoni dalam Larangan}

Tindak direktif guru yang merupakan representasi kekuasaan dengan implikasi pragmatik perintah larangan tampak pada data berikut ini.
Guru: Cerita rakyat itu banyak yang bertema istana sentris (16)

Siswa 1: $\mathrm{Bu}$, apa artinya istana sentris? (17)

Guru: Jangan dulu bertanya kalau belum dipersilakan, biarkan dulu selesai dijelaskan semua baru ada yang bisa bertanya (18)

Isi pembicaraan sesuai dengan konteks tersebut adalah pembahasan materi tentang cerita rakyat daerah dalam mata pelajaran bahasa Indonesia. Sesuai dengan tujuan pembelajaran, maka guru menjelaskan tentang cerita rakyat. Namun, saat yang bersamaan ada siswa yang bertanya tentang arti istana sentri. Saat bertanya tentang eksponen, guru melarang sebelum semua materi dijelaskan. Dalam situasi seperti ini, guru tampak mendominasi dan merepresentaikan kekuasannya di kelas yang melarang siswa bertanya sebelum dipersilakan. Tindakan guru seperti ini kurang humanis serta kurang melaksanakan fungsinya sebagai guru yang bertugas sebagai pelayan di kelas. Dominasi guru benar-benar diperlihatkan dengan membatasi ruang gerak siswa dalam bertanya yang berarti bahwa guru adalah pengatur di kelas, bukan sebagai fasilitator dan pelayan yang baik bagi siswa.

Situasi yang sama tampak pula pada data berikut yang memunculkan tuturan direktif guru yang berimplikasi pragmatis larangan.

Guru: Tugas untuk KD ini adalah menulis naskah berita. Masih ingat contoh yang telah dijelaskan?dan tema berita yang kalian tulis 
adalah bencana alam (19)

Siswa: Sudah lupa-lupa Pak. Pak, sebaiknya tema beritanya yang bebas supaya agak mudah (20)

Guru: Jangan, ikuti tema yang Bapak anjurkan!

Isi pembicaraan sesuai dengan konteks tersebut adalah pengerjaan tugas menulis berita. Sesuai dengan kegiatan saat itu, maka guru memerintahkan siswa menulis naskah berita dengan tema bencana alam. Namun, saat yang bersamaan ratarata siswa mengajukan permohonan agar tema beritanya bebas yang tentunya tidak sesuai dengan instruksi guru. Tujuan permohonan siswa adalah agar lebih mudah dalam menulis berita.Akan tetapi, permohonan siswa ditolak oleh guru yang mengimplikasikan bahwa guru memanfaatkan kekuasaan dan menonjolkan dominasinya kepada siswa.Dominasi yang lebih kongkret adalah guru bertindak dan memutuskan sesuai dengan keinginannya tanpa ada pertimbangan dari siswa. Tidak adanya kebijaksanaan guru juga menandakan otoriter sebagai penguasa di kelas, bukan sebagai inspirator dan motivator bagi siswa.

\section{4)Representasi Hegemoni dalam Pertanyaan}

Representasi hegemoni dalam pertanyaan tampak pada data berikut ini saat pembelajaran baru dimulai.

Guru: Materi kita pada hari ini ialah "paragraf persuasif'. Kegiatan kita ialah membuat atau menyusun paragraf persuasif. Lihat di LKS. Apa pengertian paragraf persuasif? Siapa yang tahu, ayo menjawab! (22)

Siswa: (Semua siswa masih dalam keadaan diam) (23)

Guru: Apa ciri-ciri paragraf persuasif! (24)

\section{Konten}

pembicaraan tersebut adalah informasi tenang materi pembelajaran dalam mata pelajaran bahasa Indonesia, yaitu menyusun paragraf persuasif. Dalam menginformasikan materi pembelajaran tersebut, guru mengajukan pertanyaan secara berkesinambungan sebagai upaya memicu dan memancing pemahaman siswa tentang paragraf persuasif. Tampaknya, tidak ada siswa yang menjelaskan dan menjawab pertanyaan guru sehingga guru mengulangi pertanyaan sebagaimana tampak pada tuturan (24).

$\begin{array}{lr} & \text { Banyaknya } \\ \text { pertanyaan secara } & \\ \text { berkesinambungan } & \text { yang } \\ \text { dilontarkan oleh } & \text { guru } \\ \text { menyebabkan siswa } & \text { sebagai } \\ \text { peserta belajar yang dikuasai } \\ \text { sehingga semakin tegang dan } \\ \text { merasa takut. Hal ini } \\ \text { disebabkan oleh anggapan } \\ \text { siswa yang selalu diserang } \\ \text { pertanyaan oleh guru. }\end{array}$

\section{5)Representasi Hegemoni dalam Penolakan}

Representasi hegemoni dalam penolakan guru terhadap siswa sering dilakukan oleh guru. 
Penolakan tampak ketika siswa menjawab pertanyaan guru dan guru menolaknya tanpa penghargaan dan pujian guru. Demikian halnya pada saat pembentukan kelompok dan sebagainya. Perhatikan data berikut ini!

Guru: $\quad$ Sebelum tiap kelompok mengerjakan tugas, perhatikan dulu penjelasan berikut ini! Anggota kelompok ditentunkan sesuai dengan nomor urut ya supaya mudah dikontrol (25)

Siswa 2: $\quad$ Bagaimana kalau selang seling kelompoknya Bu, campu laki-laki dengan perempuan? Bosan $\mathrm{Bu}$ kalau itu terus (26)

Siswa 1: Ibu tadi kan bilang sesuai urutan absen. Bagus kan kalau berdasarkan absen, agak mudah dibentuk dan tidak banyak keributan (27)

Tuturan direktif guru tersebut mengandung makna pragmatis memerintah (tuturan 25 dan 27). Berdasarkan tuturan ini dapat dinyatakan bahwa guru mengeluarkan pernyataan dan perintah yang diperuntukkan kepada siswa, yakni menganjurkan kepada siswa agar memperhatikan penjelasan guru tentang pembentukan kelompok. Instruksi guru adalah siswa harus membentuk kelompok berdasarkan urutan absen dengan tujuan kepraktisan bagi guru. Berdasarkan instruksi guru, tampak siswa mengajukan penawaran dan permintaan agar kelompok tidak ditentukan berdasarkan absen. Namun, permintaan siswa ditolak oleh guru melalui bentuk kalimat penolakan "Ibu tadi kan bilang sesuai urutan absen. Bagus kan kalau berdasarkan absen, agak mudah dibentuk dan tidak banyak keributan (27)".

\section{b. Representasi Hegemoni dalam Tindak Asertif}

Tindak asertif adalah tindak tutur yang bertujuan menginformasikan sesuatu kepada lawan bicara. Tindak asertif ini cukup potencial merepresentasikan kekuasaan guru. Gejala ini terkait dengan karakteristik wacana kelas sevagsebagai domain pendidikan dan pembelajaran.

\section{1) Representasi Hegemoni dalam Menegaskan}

Penggunaan asertif dengan bentuk menegaskan dijumpai dalam wacana kelas, termasuk di SMP Negeri 1 Bungoro Kabupaten Pangkep. Perhatikan data tuturan berikut ini!

Guru: Oh iya. Nah sekarang perhatikan semua. Masih ingat materi menulis laporan? (28)

Siswa: Ingat! (29)

Guru: Oke, siapa yang mau menjelaskan pengertian laporan! (30)

Siswa 1: Laporan tertulis hasil pengamatan (31)

Siswa 2: Hasil pengamatan seperti perjalanan! (32)

Guru: Sepertinya kalian belum memahami dengan baik tentang laporan perjalanan. Pengertian yang benar adalah bahwa laporan adalah sebuah tulisan yang menyajikan dan memaparkan hasil pengamatan secara rinci sesuai dengan 
yang terjadi di lapangan (33)

Konteks tuturan tersebut adalah guru mengajukan pertanyaan untuk mengetahui pemahaman siswa terhadap materi menyusun laporan. Hal ini tampak pada tuturan Masih ingat materi menulis laporan? (28). Pertanyaan ini direspons oleh dua siswa secara bergantian. Namun, respons dan jawaban siswa sepertinya kurang akurat menurut guru. Hal ini memicu terjadinya kekuasaan guru terhadap siswa. Dominasi guru tampak pada penegasan konsep laporan yang telah dijelaskan oleh siswa. Dalam hal ini, tampak kekuasaan guru yang menganggap dirinya yang paling benar dan sulit menerima dan mempercayai pendapat siswa dengan pernyataan sepertinya kalian belum memahami dengan baik tentang laporan perjalanan (33).

Perhatikan pula kekuasaan guru dalam konteks menegaskan berikut ini!

Guru: Nah, sekarang semua kelompok melaporkan atau membacakan di depan hasil diskusinya (34)

$$
\text { Siswa: Yang naik }
$$
siapa Pak? (35)

Guru: Salah satu di antara kalian. Kalian itu siswa yang pintar semua. Jadi, tidak perlu saling berharap dan menyuruh (36)

Siswa: $\quad$ Iya pak. (37)

Siswa: Karakteristik karangan deskripsi salah satunya adalah mendeskripsikan suatu objek apa adanya (38).

Siswa: Oke, saya setuju dengan pendapat kelompok Anda (39).

Guru: Semua pendapat belum jelas mengarah pada ciri-ciri atau karakteristik deskripsi (40).
Konteks tuturan di atas termasuk tuturan yang diungkapkan melalui kalimat perintah, sehigga lebih mengindikasikan makna pragmatik imperatif perintah. Untuk membuktikan secara pasti bahwa tuturan tersebut merupakan imperatif dengan makna suruhan, maka pada kegiatan bertutur yang sesungguhnya tampak pada tuturan sekarang semua kelompok melaporkan atau membacakan di depan hasil diskusinya. Guru menyuruh semua kelompok agar melaporkan hasil diskusinya. Namun, saat itu ada indikasi yang ditemukan guru bahwa ternyata rata-rata kelompok tidak bersedia tampil melaporkan pekerjaan kelompoknya. Dengan bujukan guru, akhirnya perwakilan kelompok juga menampilkan pekerjaan kelompoknya.

\section{2) Representasi Hegemoni dalam Menunjukkan}

Tindak asertif dengan bentuk menunjukkan tampak dalam wacana kelas.Daya ilokusi bentuk ini membuat lawan tutur memahami dan mengetahui sesuatu sebagaimana ditunjukkan oleh tuturan penutur.Daya ilokusi ini, terutama tuturan guru cenderung merepresentasikan kekuasaan. Perhatikan data berikut ini!

Guru: Sekarang perhatikan baik-baik karya sastra itu! (41)

Siswa: Semuanya Pak? 
Banyaknya de e (42)

Guru: Tidak banyak namanya itu, hanya gambarnya yang besar. Kalau

kalian hayati gambar itu sebenarnya bagus dipelajari (43).

Guru:Nah, didiskusikan dengan teman sebangkunya kecenderungan gagasan yang kira-kira melatarbelakangi penciptaan karya itu? (44).

Siswa: (semua terdiam tanpa ada yang menjelaskan latarbelakang penciptaan karya sastra yang ditampilkan guru (45)

Guru:Berarti tidak kalian tidak pernah membaca bukunya tentang karya sastra. Di situ ada penjelasan tentang latar belakang penciptaan karya sastra (46).

Pada data tersebut tampak tuturan guru yang berwujud asertif (46). Tindak asertif guru tersebu dipicu oleh instruksi guru sebelumnya yang menugasi siswa agar mendiskusikan materi tentang yang melatarbelakangi penciptaan karya sastra yang sedang dibahas saat itu. Namun, hasil diskusi siswa tidak menemukan jawaban tentang latar belakang penciptaan karya sastra yang diajarkan guru saat itu. Tidak adanya jawaban siswa tentang latar belakang karya sastra, memicu guru terjadinya tindak asertif guru yang menunjukkan dan menginformasikan bahwa latar belakang yang dimaksud ada di buku pegangan siswa. Pengalihan perhatian dan sumber jawaban tersebut mengindikasikan terjadinya hegemoni dan kekuasaan guru. Guru memperlihatkan kekuasaannya sebagai sosok pengarah yang selalu diikuti oleh siswa.

Pengalihan sumber jawaban yang dilakukan oleh guru sebagaimana tergambar dalam konteks tuturan tersebut mengindikasikan bahwa guru tidak berupaya memberikan penjelasan berdasarkan kepakaran dan pengetahuannya, justru mengalihkan dan mengarahkan siswa untuk melihat jawaban yang ada di buku. Hal ini sebenarnya tidak perlu dilakukan oleh guru di kelas jika melihat perannya sebagai pusat dan pemberi informasi atau pengetahuan. Tidak adanya upaya guru menjelaskan sendiri, menimbulkan kekuasaanya di kelas dan menganggap bahwa siswa adalah objek yang mudah diatur dan dipengaruhi.

\section{Perhatikan data berikut ini!}

Guru: Materi kita pada hari ini ialah puisi lama dan puisi baru. Kegiatan kita ialah membedakan kedua jenis puisi tersebut. Lihat di LKS. Apa puisi lama dan baru? Siapa yang tahu? (47)

Siswa 1: Puisi lama adalah puisi yang terikat oleh pola persajakan(48)

Siswa 2: Puisi lama kayaknya lebih menonjolkan persamaan sajaknya, itu yang baris-baris akhirnya misalnya a a a (49).

Guru: Ada jawaban yang lain? Ok kalau tidak ada dengarkan baik-baik penjelasan ibu bahwa puisi lama adalah puisi yang terikat oleh pola persajakan atau istilahnya adalah rima, biasanya terdiri atas 4 baris tiap bait (50)

\section{Berdasarkan data} tersebut tampak kekuasaan atau hegemoni guru terhadap siswa. Kekuasaan guru ditunjukkan dalam proses tanya jawab. Guru menunjukkan kkeuasaannya 
kepada siswa bahwa jawabannyalah yang paling tepat serta mengabaikan pendapat dan jawaban siswa yang sesungguhnya juga memiliki kebenaran. Namun, tidak ada upaya guru dalam memberikan penghargaan atas jawaban siswa karena guru memiliki tujuan, yakni menunjukkan

kepakaran/kehebatan serta menyampaikan pendapatnya yang dianggap benar sehingga siswa dapat meyakini kebehatan seorang guru. Hal ini tampak pada tuturan guru (50).

Berbeda seandainya guru terlebih dahulu memberi pujian dan penilaian terhadap jawaban siswa, lalu guru melanjutkan jawaban dengan tujuan penegasan, maka akan terhindar dari hegemoni guru. Selain itu, tindakan pujian dan penghargaan akan menjaga jarak dan simpati siswa terhadap guru.

\section{3) Representasi Hegemoni dalam Mempertahankan}

Tindak asertif dengan bentuk mempertahankan juga ditemukan dalam wacana kelas. Bentuk mempertahankan lebih cenderung terjadi di kelas yang menerapkan teknik pembelajaran yang mendorong siswa terlibat aktif dalam pembelajaran. Selain itu, juga tampak pada pembahasan materi pembelajaran yang kadangkadang siswa dna guru mempertahankan ego dan keinginannya.

Tuturan guru dengan bentuk representasi hegemoni mempertahankan tampak pada data berikut ini.

Guru: Kalau kalian menyajikan materi, seharusnya tidak berdiri, duduk saja (51)

Siswa: Tapi kalau kita lihat diskusi pada umumnya, rata-rata berdiri ji juga semua Bu. (52)

Guru: Iya, tapi itu salah menurut Ibu! Seharusnya duduk supaya terkesan lebih meyakinkan penyajian materinya (53)

Konteks tuturan tersebut adalah presentasi kelompok. Dalam proses presentasi kelompok untuk menyajikan materi, tampaknya salah satu peserta penyaji, menyajikan materi yang tidak sesuai dengan keinginan guru. Hal ini memicu kritik guru dengan mengajukan saran tentang proses yang ideal dalam menyajikan materi yakni sebaiknya dalam keadaan duduk di meja diskusi. Saran guru tersebut kembali direspons oleh siswa dengan implikasi menolak saran guru dengan alasan bahwa proses yang dilakukan dalam menyajikan materi sudah tepat karena hal itu sering disaksikan dalam kegiatan forum resmi.

Penolakan siswa terhadap saran dan tawaran guru lebih memicu kekuasaan guru. Saat proses itu, guru tetap bertahan pada pendapatnya yang kemudian menyurutkan dan mematahkan pendapat siswa. Kondisi demikian merupakan potret hegemoni dan kekuasaan guru yang segalagalanya adalah bergantung keputusan guru tanpa ada keterlibatan siswa dalam 
penetapan keputusan. Hegemoni ini tentu membatasai ruang gerak dan kebebasan siswa untuk terus berkreasi dalam proses pembelajaran.

Perhatikan pula data berikut ini!

Siswa: $\mathrm{Bu}$, yang ibu tadi jelaskan bahwa membaca tabel itu seharusnya dilakukan dengan secara horisontal, bagaimana kalau membaca tabel secara vertikal, kan sepertinya juga bagusji juga untuk menemukan isi tabel itu bu (54).

Guru: $\quad$ Yang benar adalah yang secara horisontal seperti yang ibu jelaskan dan anjurkan tadi (55).

Siswa: Jadi, itumi yang benar Bu?

Hegemoni yang tampak sesuai dengan konteks tuturan tersebut adalah hegemoni guru dalam mempertahankan pendapatnya tentang cara membaca tabel. Walaupun pendapat siswa sudah benar tentang membaca tabel dengan vertikal, namun guru seolah-olah tidak mau menerima masukan dan saran dari siswa. Sebaliknya, guru lebih mengutamakan pendapatnya dan selalu dijadikan acuan bagi guru. Artinya, guru sellau menganggap bahwa pendaptnyalah yang benar harus diikuti oleh siswa.

Kekuasaan kepakaran dan pengetahuan guru tersebut mengindikasikan terdapatnya perbedaan status dan jarak pengetahuan antara siswa dan guru. Selain itu, perbedaan tersebut menyebabkan siswa tertekan dan segala sesuatu selalu mengharapkan dari guru karena pendapat dan kreativitas siswa tidak dihargai oleh guru. Jadi, konteks tuturan tersebut menggambarkan kekuasaan dan hegemoni guru yang menghilangan kreativitas dan ide siswa.

\section{c. Representasi Hegemoni dalam Tindak Ekspresif}

Tidak ekspresif ternyata juga merepresentasikan kekuasaan guru terhadap siswa. Tindak tutur ekspresif merupakan bentuk tindak tutur yang menyatakan apa yang dirasakan oleh penutur. Tindak tutur ini, penutur mengekspresikan keadaan psikologis. Dalam interaksi belajar mengajar di SMP Negeri 1 Bungoro Kabupaten Pangkep, representasi hegemoni diekspresikan dalam wujud kemarahan guru. Hal ini tampak pada data berikut.

Siswa: (Semua siswa ribut dalam melaksanakan diskusi kelompok) (57).

Guru: Kok ribut semua, bagi kelompok yang ribut akan dikenakan pengurangan nilai. Tidak perlu ribut, kerja saja dengan tenang bersama anggota kelompoknya masing-masing (58).

Siswa: Iya Pak, (semua siswa merespons guru dengan kalimat penerimaan) (59)

Pada data tersebut tampak hegemoni guru dalam interaksi belajar mengajar di SMP Negeri 1 Bungoro Kabupaten Pangkep. Wujud hegemoni tersebut direpresentasikan pada saat guru memarahi siswa yang ribut. Guru memanfaatkan kekuasaannya di kelas dengan kemarahan yang berbuntut pada hukuman dan acnaman kepada siswa yang ribut. Padahal, guru semestinya memahami kondisi kelas bahwa dalam berdiskusi, tidak bisa lepas dari keributan karena siswa saling berembuk dan menyatukan pendapat. 
Hegemoni guru terhadap siswa tampakpula pada data berikut ini.

Guru: Ibu mau bertanya kepada kalian, mengapa tidak ada satu pun yang menyetor tugas KD 3.1. Ibu kan sudah bilang, tugasnya terakhir hari Senin, tapi sampai sekarang belum ada yang menyetor (60).

Siswa 1: Ibu, katanya ketua kelas, tidak dikumpul karena mau dibahas bersama di kelas. (61).

Guru: Tapi, bagaimana mau dibahas, waktu untuk materi itu sudah selesai, masih banyk materi yang perlu dipelajari (62)

Konteks tuturan tersebut adalah guru bertanya kepada seluruh siswa mengenai penyetoran tugas KD 3.1.Dalam situasi ini, tak satu pun siswa yang menyetor tugas sehingga guru bertanya alasan sehingga siswa tidak menyetor tugas.Dalam bertanya, tampak guru mengekspresikan kemarahannya kepada siswa dengan tidak ada yang mengumpulkan tugas sesuai dengan waktu yang telah ditentukan.

Tuturan guru yang dituturkan dengan disertai oleh ekspresi dan nada tinggi (menekan, menegur, memarahi) dalam interaksi belajar mengajar tampak ketika guru mengeluarkan perintah dna teguran dnegan nada tinggi sebagaiman konteks tuturan berikut ini.

Guru:

Harap diperhatikan

(63)

Siswa 1: $\quad$ Iya Bapak (64)

Siswa 2: Bagaimana mau memperhatikan Pak, yang lain banyak ribut dan bercerita (65)

Guru: Jawaban kalian itu sebenarnya membingungkan semua. Lain ditanyakan lain jawabannya. Kalian dengar tidak, kalian kira bapak tidak capek ngomong terus (66).

Situasi pembicaraan sesuai dengan konteks tuturan tersebut adalah menegangkan dengan disertai kemarahan guru. Guru mengekspresikan kemarahannya kepada siswa yang tidak mamu memperhatikan penjelasan guru. Dalam mengekspresikan kemarahan tersebut tersirat makna pragmatis menyalahkan. Hal yang disalahkan oleh guru adalah semua jawaban siswa yang tidak sesuai dengan permintaan soal. Hal ini tampak pada tuturan jawaban kalian itu sebenarnya membingungkan semua. Lain ditanyakan lain jawabannya. Jadi, kemarahan guru dipicu oleh ketidakbenaran dan ketidakjelasan jawaban siswa yang justru membingungkan bagi guru.

\section{Representasi Fungsi Hegemoni Tindak Tutur Guru Pada Pembelajaran Bahasa Indonesia di SMP Negeri 1 Bungoro Kabupaten Pangkep}

Representasi fungsi hegemoni adalah suatu tujuan dan keinginan guru dalam merepresentasikan tutran sebagai bentuk preventif (pencegahan), suportif (pendorong), dan korektif (perbaikan).Representasi fungsi hegemoni di SMP Negeri 1 Bungoro Kabupaten Pangkep yang ditemukan terdiri atas bentuk preventif (pencegahan), suportif (pendorong), dan korektif (perbaikan).

a. Preventif (Pencegahan)

Dalam interaksi kelas di SMP Negeri 1 Bungoro Kabupaten Pangkep, ditemukan fungsi hegemoni sebagai bentuk preventif atau pencegahan sebagaimana tampak pada data berikut ini. 
Guru:

Menurut kalian, apa perbedaan kalimat pertama dengan kalimat utama (67) Siswa 1: Kalau saya Pak, bedaki. (68)

Guru: $\quad$ Ya, jelas beda (69)

Siswa 2: $\quad$ Kalau saya Pak, kita lihat dulu pengertian kalimat secara umum. Kalimat adalah gabungan beberapa kata,frase, klausa.... (70)

Guru:

Tidak perlu berteori panjang lebar dulu. Langsung saja dijelaskan perbedaan kalimat utama apa, kalimat utama apa. Supaya jelas, dan yang lain temannya bisa tahu juga (71).

Konteks pembicaraan tersebut adalah pembahasan tentang penentuan ide pokok paragraf.Untuk menentukan ide pokok paragraf, tentu harus dipahami terlebih dahulu tentang kalimat utama dan kalimat pertamaa serta kalimat penjelas.Pada saat pembaasan itu, muncul pertanyaan guru tentang perbedaan kalimat utama dan kalimat pertama.Pertanyaan ini direspons oleh siswa 2 dengan menjawab perbedaan kalimat utama dan kalimat pertama.Namun, sebelum siswa menjawab perbedaannya, terlebih dahulu diawali oleh penjelasan tentang kalimat secara umum.

Pada konteks lain, terdapat hegemoni guru teradap siswa sebagaimana tampak pada data berikut ini.

Guru: Pada waktu mengikuti pelajaran ini, hendaknya kalian mengikuti aturanaturtan. Tentunya ada penilaian yang namanya penilaian proses. Jadi, yang tidak memperhatikan tentunya tidak akan diberi nilai. Bahkan kalau perlu ada pengurangan nilai (72)

Siswa 1: (seluruh siswa mendengarkan dengan tekun) (73) Dalam kutipan tersebut tampak seorang guru menyampaikan aturan penilaian yang akan dilaksanakan pada pertemuan saat itu. Penyampaian aturan itu merupakan upaya guru untuk mencegah agar siswa tidak berperilaku menyimpang atau tidak mengikuti pembelajaran dengan baik. Penyampaian aturan itu merupakan instrumen hegemoni bagi guru agar siswa tidak berperilaku kontraproduktif ketika pembelajaran sedang berlangsung.

Guru: Baiklah, pada hari ini kita akan melakukan diskusi. Ada beberapa hal yang harus kalian perhatikan sebelum melaksanakan diskusi. Kelompok yang tampil masingmasing silakan memperkenalkan anggotanya sambil menyebutkan nomor urut absennya. Yang lain tolong perhatikan baik dan tolong mempersiapkan pertanyaan dengan baik terhadap makalah yang disajikan (74)

Siswa:

Berdasarkan kutipan tersebut tampak bahwa guru sedang memberikan pengarahan sebelum dilaksanakan diskusi kelas. Dalam konteks itu, guru mempunyai kekuasaan untuk mengarahkan agar diskusi yang dilaksanakan berlangsung secara efektif. Oleh karena itu, tuturan guru tersebut telah memfungsikan kekuasaannya untuk mencegah terjadinya ketidakefektifan diskusi dengan cara memberikan 
pengarahan tentang hal yang harus dilakukan siswa ketika berdiskusi.

\section{b. Korektif (Perbaikan)}

Fungsi kekuasaan adalah sebagai tindakan korektif. Fungsi ini mengacu pada upaya memperbaiki proses pembelajaran, mendisiplinkan siswa yang tidak patuh pada aturan, dan sebagainya. Biasanya guru menggunakan fungsi kekuasana ini setelah siswa memilih menghindari pengaruh kepada mereka dengan mengesampingkan aturan dan prosedur.Perilaku siswa yang tidak sesuai memicu sikap guru untuk menolak, memberikan hukuman, dan mengingatkan untuk membetulkan kembali.

Berikut ini data hegemoni guru terhadap siswa dalam konteks perbaikan perilaku siswa yang tidak sesuai dengan aturan dalam pembelajaran.

Guru: Ibu dengan laporan bahwa ternyata ada beberapa siswa yang tidak mengerjakan tugas yang ibu berikan tadi. Walaupun saya tidak ada di kelas, kalian tetap harus kerjakan dengan baik tugas itu. Bahkan ada yang keluar masuk kelas. Jadi, terpaksa ibu akan berikan sanksi yang lebih berat nanti. Jadi, lain kali jangan ada yang begitu lagi ya! (75)

Siswa: (terdiam mendengarkan ceramah guru yang sedang marah) (76)

Berdasarkan konteks tuturan tersebut, tampak hegemoni guru dengan direpresentasikan sebagai fungsi korektif. Cara yang dilakukan dalam negoreksi agar siswa tidak lagi mengulangi kejadian yang sama adalah memberikan sanksi/hukuman.

Hegemoni guru yang tampak sesuia dengan konteks tuturan tersebut adalah kekuasaan terhadap siswa. Dalam hal ini, guru sebagai penguasa dan siswa sebagai objek yang dikuasai sehingga muncul

kebebasan guru meninggalkan kelas saat pembelajaran. Bagi siswa yang ditinggalkan dengan titipan tugas-tugas, juga punya hak untuk keluar dan bahkan tidak mengerjakn tugas karena guru yang diharapkan memebrikan tuntunan dalam mengerjakan tugas tidak ada. Boleh saja, siswa yang tidak mengerjakan tugas tahu cara kerjanya sehingga wajar jika tidak mengerjakan dan keluar kelas. Namun, kondisi ini tidak berterima bagi guru. Guru justru memarahi siswa dengan sanksi tugas yang berat sebagai bentuk pelajaran dna koreksi diri siswa agar tidak mengulangi tindakan tersebut.

Guru: Bagi kelompok penyaji jangan dulu disimpulkan satu per satu jawaban atas pertanyaan yang ada. Akan lebih bagus jika nanti sekaligus di akhir presentasi baru disimpulkan semua (77)

Siswa (penyaji): Maksudnya Ibu, supaya setiap pertanyaan, jelas jawabannya (78)

Guru: Masalahnya waktu, supaya kelompok lain bisa tampil juga (79)

Konteks tuturan tersebut pelaksanaan diskusi kelompok.Dalam menyajikan materi diskusi, tampak penyaji menerapkan strategi diskusi dengan menyimpulkan satu per satu setiap jawaban pertanyaan.Hal ini memang merupakan sesuatu yang tepat agar setiap masalah memiliki jawaban yang pasti, serta tujuan penyimpulan tersebut adalah sebagai penguatan setiap jawaban masalah.

\section{Simpulan}


Berdasarkan penyajian uraian sebelumnya, disimpulkan hasil penelitian ini sebagai berikut: (1) Hegemoni dalam bertindak tutur guru pada pembelajaran bahasa Indonesia di SMP Negeri 1 Bungoro Kabupaten Pangkep direpresentasikan dalam tindak direktif, asertif, dan ekspresif. Representasi hegemoni dalam tindak direktif, guru sebagai pemegang kekuasaan di kelas menggunakan lima jenis direktif, yaitu perintah, permintaan, larangan, persilaan, pertanyaan, dan penolakan. Penggunaan tindak tutur tersebut mempunyai kadar retriksi tinggi sehingga cenderung merepresentasikan kekuasaan yang dominatif. Representasi hegemoni dalam tindak asertif, guru sebagai pemegang kekuasaan di kelas menggunakan tiga jenis tindak asertif, yaitu menegaskan, menunjukkan, mempertahankan. Penggunaan tindak asertif ini menunjukkan sifat kekuasaan yang dominatif terhadap siswa. Tindak ekspresif direpresentasikan dalam bentuk kemarahan guru yang juga memiliki kadar retriksi yang tinggi sehingga bersifat dominatif. (2) Fungsi hegemoni tindak tutur guru pada pembelajaran bahasa Indonesia di SMP Negeri 1 Bungoro Kabupaten Pangkep direpresentasikan dalam tindak preventif dan korektif. Terkait dengan tindakan preventif, hegemoni difungsikan untuk mencegah pelanggaran aturan dalam pembelajaran. Adapun tindakan korektif, hegemoni difungsikan untuk memperbaiki tindakan siswa, perilaku siswa dalam belajar, dan cara kerja siswa di dalam mengerjakan tugas.

\section{DAFTAR RUJUKAN}

Alwasilah, Chaedar. 1993. Pengantar Sosiologi Bahasa. Bandung : Angkasa.
Arman. 1997. "Analisis Implikatur Percakapan Bahasa Indonesia Penggalan Percakapan Harian Jawa Pos."Tesis Program Pascasarjana Universitas Hasanuddin.

Austin, J. L 1962. Performative Utterances.dalam Martinich, A. P. (Ed), The Philosophy of Language (halaman 130-139). New York: Oxford University Press.

Biklen and Bogdan, R.C., S.K. 1982. Qualitative Research for Education, An Introduction toTheory and Methods. Boston: Allyn and Bacon.

Brown, G., \& YuleGeorge. 2006. Analisis Wacana. Diterjemahkan oleh Soetikno. Jakarta: PT Gramedia Pustaka Utama.

Chaer, Abdul dan Agustina Leonie. 1995. Sosiolinguistik (Perkenalan Awal). Jakarta: Rineka Cipta.

Depdikbud. 2005. Kamus Besar Bahasa Indonesia. (Edisi Ketiga). Jakarta: Balai Pustaka.

Eriyanto. 2003. Analisis Wacana. Yogyakarta: LKIS.

Fairclough, Norman. 1998. Critical Discourse Analysis. London: Longman.

Ibrahim, A. S. 1994. Panduan Penelitian Etnografi Komunikasi. Surabaya: Usaha Nasional.

Ibrahim, A. S. 1996. "Bentuk Direktif: Kajian Etnografi Komunikasi”.Disertasi. Tidak 
Diterbitkan. Surabaya: Universitas Airlangga.

Jumadi. 2005. Representasi Kekuasaan dalam Wacana Kelas. Jakarta: Depdiknas.

Leech, Geoffrey. 1993. Prinsip-prinsip Pragmatik. Terjemahan M.D.D. OKA. Jakarta: Penerbit Universitas Indonesia.

Louise, Cummings. 2007. Pragmatik Sebuah Perspektif Multidisipliner. Jakarta: Pustaka Belajar.

Mey, J.L. 1996. Pragmatics an Introduction. New York: Blackwell Oxford UK and Cambridge USA.

Miles, M. B. \& Huberman, A. M. 1992.Qualitative Data Analysis.Diterjemahkan oleh Tjetjep Rohendi R, 1992. Jakarta: Universitas Indonesia.

Moeliono, Anton Moedarto Eds. 2005.Tata Bahasa Baku Bahasa Indonesia.Jakarta: Depdikbud.

Moleong, L. J. 2001. Metodologi Penelitian Kualitatif. Bandung: Remaja Rosdakarya.

Rahardi, R. Kunjana. 2000. Imperatif dalam Bahasa Indonesia. Yogyakarta: Duta Wacana University Press.

Ridwan, H.T.A. 1998. "Pokok-pokok Pikiran mengenai Peran Bahasa dalam Kehidupan Bermasyarakat, Berbangsa, dan Bernegara."Makalah Kongres
Bahasa Indonesia VII Jakarta: Depdiknas.

Santoso, K. B 1990. Problematika Bahasa Indonesia (Sebuah Analisis Praktis Bahasa Baku).Jakarta: Rineka Cipta.

Searle, J.R. 1976.Indirect Speech Acts.Dalam Peter Cole dan Jerry L. Morgan. (Eds). Syntax and Semantic Volume 3 Speech Acts (hlm. 59-82). New York: Academic Press.

Thansoulas, Dimitros. 2001. Language and Power in Education. Oxford: Oxford University Press. 